\title{
The Application of Asa Berger Humour Technique by Sabri Yunus from The Dramaturgy Perception in "Karoot Komedi"
}

\author{
$\bowtie$ Mardiana Binti Ismail ${ }^{1}$, Indrayuda Indrayuda ${ }^{2}$, \\ Mohd Effindi Bin Shamsuddin ${ }^{3}$ \\ ${ }^{1}$ Faculty of Music and Art Performance, Sultan Idris Education University Malaysia \\ ${ }^{2}$ Department of Drama, Dance and Music, Faculty of Language and Art, \\ Universitas Negeri Padang, Indonesia \\ ${ }^{3}$ Socio- Cultural Malay and Malay Language Department, \\ Academy of Malay Studies, University of Malaya, Malaysia
}

Received: January 15, 2018. Revised: October 25, 2018. Accepted: December 10, 2018

\begin{abstract}
This paper aims to introduce Sabri Yunus as a Dramaturgy in Comedy especially in the popularised television program called "Karoot Komedi". The method used in conducting this research is qualitative descriptive through a survey. The data was obtained through observation, interview and also documentation studies. The object of the observation is the drama performance "Karoot Komedi" by Sabri Yunus. The researcher is the instrument for this research, who is also in charge in collecting the data, conducting the observation and interpret the research questions based on the object. The analysis was able to be conducted successful using the model Gotthold Ephraim Lessing, Miles and Huberman. The validity of the data obtained is examined by using the triangular method and also by the co-worker's evaluation and insight. The finding of this paper shows that the Humour elements are correlated to the spontaneous response and behaviour of the audience such as laughing and smiling. Every individual has different spontaneous response and behaviour as it depends on the audience's interest, inclination and also understanding towards a humour issue displayed to them. Based on two episodes of the Karoot Komedi, the Dramaturgy in Comedy Sabri Yunus applied the Humour techniques during the performance. To sum up each episode as a whole, each episode are assessed based on 4 categories which are Language, Logic, Identity and action.
\end{abstract}

Keywords: Sabri Yunus; Dramaturgy in Comedy; Humour; Lelucon; Karoot Komedi

How to Cite: Ismail, M. B., Indrayuda, I., \& Shamsuddin, M. E. B. (2018). The Application of Asa Berger Humour Technique by Sabri Yunus from The Dramaturgy Perception in "Karoot Komedi". Harmonia: Journal of Arts Research And Education, 18(2), 162-171.

\section{INTRODUCTION}

For further explanation on the research and this article topic, researcher share some insight on the establishment of a non-profit organization and its member who voluntarily handle the Dramaturgy data. The organization is called Literary Managers and Dramaturgs of America which was built on the year 1985. The members of this organization are people who work in the literature field and have a firm belief that theatre is an important form of the art performance and have the power

\footnotetext{
${ }^{\square}$ Corresponding author: Tanjoeng Malim Perak 35900, Malaysia

E-mail: mardiana.yang@gmail.com
} 
to main, teach and also change an individual and its local community. Kerkhoven (2009) in his article, A constant movement, feels the same worry as the development of art performance in Europe was at a critical state at the time. The neoliberal politics and economy have evoked a conflict which caused the value of spiritual in the performance to decrease.

In the article, Short comments on the notion of European Dramaturgy, Kerkhoven (1998) discussed how dramaturgy starts to play an important role in a performance. Furthermore, the Asian Dramaturgs' Network Inaugural Symposium 2016, Asian Dramaturgs' Network Meeting 2017, Asian Dramaturgs' Satelite Symposium 2017 dan Asian Dramaturgs' Network Satelite Symposium 2018 organized by the symposium shows the efforts pour by the organizers and participants for the dramaturgy profession to get acknowledgment from the public.

Therefore, based on the issue mentioned previously, it wise to broaden the role of dramaturgy. However, the application of dramaturgy is still new to Malaysia at the moment. Azman Ismail (2007) states that the dramaturgy approach was still foreign in the drama performance context in Malaysia even it is not the case for the western countries.

It is a pity that there is little to no direct teaching on dramaturgy in the art Art Education Charlene Performance system. There is no review on the method, tools, function or role of dramaturgy in the art performance context in Malaysia.

According to Behrndt, "........ dramaturgical work is about relationships: 'this is a relationship, a dialogue, an interrelation between two or more people with the aim of creating or developing a piece of performing artwork" (Behrndt, 2015, p. 254). In Malaysia, Dramaturgy needs to face issues on the professional relationship with the performancemaker. Behrndt stated that dramaturgy and the performance- maker (the theater director, dance instructor, artist, producer and curator and also other field relates to dramaturgy) need to have communication skills.
With the proficient communication skill and sufficient knowledge on dramaturgy, people will feel comfortable and able to share their knowledge and experience with the performance-maker while they are in the art performance industry(Behrndt, 2015, p. 254).

According to The Head Director of Istana Budaya, Datuk Mohamed Juhari Shaarani "Istana Budaya minta pelawak tidak sentuh isu agama dalam pertunjukan. Pelawak di negara ini dinasihatkan agar meletakkan batasan selain tidak menyentuh sebarang isu sensitif terutamanya soal agama dan kaum dalam pertunjukan ......." (Mohd Al Qayum Azizi, 2014). In other words, a comedian is advised to not touch on any issues involving the religion or any other sensitive issues such as religion and race in the performance that may arouse unwanted problems within the society. The reaction evokes by this issue shows how important is the dramaturgy role in performance as dramaturgy is an individual who will assess, giving feedbacks,, be an intermediary or a reference for a workpiece.

There are two aims for this paper which are to interpret Sabri Yunus role as a dramaturgy through the modification of the television program Karoot Komedi and also to decipher Sabri Yunus's performance idea through research analysis towards implementation of hilarious acting in the television program Karoot Komedi. This paper also questions on the (i) role of dramaturgy especially in managing the television program Karoot Komedi and (ii) the application of dramaturgy on the acting movement, action and also the use of language to help the development of the performance in Karoot Komedi.

Dramaturgy refers to the art or drama writing techniques which were created in a form of art of the theatre. The word 'dramaturgy' originates from a Greek word, 'dramaturge' (Romanska, 2016, p..2) which means the principles of dramatic arts. Dramaturgy is a technique in arranging a dramatic performance.Comedy relates to laughter (ketawa) and humor (humor) (Sikana, 2013). Humor in a comedy 
performance can give a certain quality and value towards it (Romanska, 2016). Dramaturgy is essential in an art performance, especially in understanding the world of drama and theatre. This paradigm needs to be acknowledged as the definition of dramaturgy originates from the art performance field especially in the making of a drama text.

Barba (2010, p. 83) states that dramaturgy will only be able to identify through the drama text writings and the process of theater performance which involves the accumulation action and the actors' movement, actions which suits the scenes throughout the performance, music, lighting, sound effect, voice projection and props used in a performance. Meanwhile Harymawan (1988) states that dramaturgy is an individual who creates, discovers and also interprets an issue; before, during and after the performance, in each piece.

Moreover, Erving Goffman had discovered the dramaturgy theory which focuses on his views towards The self. For instance, The Presentation of self in everyday life (1955), talks about Goffman's view on the process and meaning from what is known as interaction (man to man). Referring to the self-realization concept and The Self Mead, Goffmn came back with a role theory as a basic Dramaturgy theorist. Goffman takes the prediction of individual life as a drama performance, complete with the setting of the place and an actor to play the role of the 'life' (Azizah, 2012, p. 36).

Based on the development of dramaturgy in Malaysia, the definition of dramaturgy is rarely used among the art performance researchers. In this context, Raliby (1956) introduced dramaturgy as knowledge or skills in acting and also the drama author. Hussain (1988) also introduces the word dramaturgy in his research as knowledge about the art of poetry and art of the role in a drama.

This research tempts to carry out research that will be beneficial towards the education of art in Malaysia. There is various content in this research that could be practiced by activist and art performance teachers and art performance promoters in order to create an intellectual workpiece especially comedy performance.

According to the examples chosen for this paper, it can be a beneficial research resource in the future. Furthermore, it can also add more references and inspire the future researchers of the art industry.

\section{METHOD}

Qualitative and observation are the main method used in the analysis the information gathered for this paper. The source of data obtained are mainly from the observation from the Karoot Komedi performance and the interview with the Comedian figures, actors, Dramaturgy specialist and also Sabri Yunus as the key information.

This paper centers on the application of the Asa Berger Humour technique by introducing four main aspects which are the language, the logic, the identity and the actions used by the Dramaturgy Sabri Yunus in the television program "Karoot Komedi". The research subject relies on the aspect of (i) Language. Through language, humor can be created by speaking rhetorically (Bombast), playing with the sound of words pronounced, (Infantilism), conveying a message which has a meaning opposite than its literal meaning (Irony), misinterpreting the situation (misunderstanding), using wordplay (Pun), having a discussion with quick response or feedback (repartee), addressing someone in a dismissive manner (ridicule), convey a sharp remark towards someone (sarcasm), criticizing a public figure using humor or exaggeration (satire), condemning any issue that hints of sexual innuendo (sexual allusion), and also outplaying someone by asking a question with a humor based statement (outwitting). Aspect ii) Logic. Humour can surface in one's mind through impolite manners (irreverent behaviour), laughing at someone's misfortune(malicious pleasure), unreasonable action or irrational situation (absurdity), occasion which happens without plan (coincidence), surprise the audi- 
ence with a drastic and an unpredictable changes (conceptual surprise), a situation which portrays dismay or sorrow with humor elements (disappointment), acting naive or innocent (ignorance), repetition of an action or a situation (repetition), and also by a conservative person with a indecisive personality (rigidity).

The third (iii) aspect is identity. Humour can be created by the identity of a character through an object or animal which possess human characteristics (anthropomorphism), build a character with an unusual behaviour (eccentricity), a reserved and awkward character (embarrassment), characters which display mysterious and unpleasant form (grotesque appearance),imitating one's appearance or action (imitation), direct or indirectly impersonate another person's character (impersonation), mimicking a style of a nobleman(parody), wearing an object with a bigger or smaller measurement (scale), stereotype, someone taking in a different form (transformation), or build drastic physical and visual changes(visual surprise).

Last but not least, the fourth (iv) aspect is action. Physical action or also the non-verbal technique of humor action. As a guidance, action which refers to the Asa Berger Humour is as such examples; using the whole body with maximum energy (clownish behaviour), display the act of awkwardness or careless in a movement (clumsiness), an act of chasing someone (chase), acting excessively on a scene (exaggeration), making comical facial expression(peculiar face), use unusual and amusing music (peculiar music), displaying comical sounds (peculiar sound), using hilarious voices (peculiar voice), harsh physical humor (slapstick), and also movements with high or low speed(speed).

The analysis is done with the guidelines from the Gotthold Ephraim Lessing, Miles and Huberman Model. The researcher also refers to the forms and contents from the television program "Karoot Komedi" in order to obtain the cultural definition from this research. Meanwhile to strengthen the validity of the findings, this data is assessed through the triangular method, member check and also discussion among the co-writers.

\section{RESULTS AND DISCUSSIONS}

\section{Sabri Yunus}

Mohd Sabri Yunus or his stage name, Sabri Yunus is an artist comedian of the second generation in Malaysia and also an activist in theater performance, dramas and films which mainly based on comedy. Looking at his previous achievements and awards throughout the years he had invested as an activist in this industry, Sabri Yunus is the most suitable subject to be the primer research sample for this paper. Sabri Yunus's active participation in "Karoot Komedi" and his previous achievements gained such as TV Best Male Comedian Award in Seri Angkasa Award in 2005, Popular TV Artist Male Comedian in Anugerah Bintang Popular in 1993,1994, 1996 and 2000 and also TV Best Comedian Male Actor Award in Anugerah Lawak Warna in 2013 enable the researcher to narrow the scope and focus on the important information to about Dramaturgy in Comedy

\section{Dramaturgy in Comedy}

According to the research done by Bolton (2011), it is shown that 'explaining and exploring the concept of Dramaturgy has been the focus of the researchers or decades even when it has been mentioned previously by G.E Lessing in Hamburgische Dramaturgiie. The reflection findings in Bolton's research states that the dramaturgy approach can be applied through 'script-led' or 'non-script-led'. 'script-led' concept is applying the dramaturgy concept in texts or even printed scripts while 'nonscript-led' is applying the concept without using any written sources. Bolton stated that 'script-led' concept is the application of dramaturgy in making a connection between the texts and the performance while for 'non-script-led' the application of dramaturgy is to make a connection between scenario and the performance based on a specific context. However, the performan- 
ce needs to covers issues on social, economics, politics and other relevant local community topics, whether the writer decided to use 'script-led' or 'non-script-led' concept to be practice in the performance.

Bolton views a Dramaturgy as an innovative person who is creative and able to create a dynamic and quality workpiece. The approach of Dramaturgy in Comedy practiced by Sabri Yunus able to produce prestige workpiece which will able to help the community to overcome their problem by practicing the issues and solution presented in the performance. This dramaturgy solution was once presented by Romanska (20160, p. 186):

as 'dramaturgy as a creative practice defined in relation to a shared set of attitudes towards the production and reception of theatre, and argues that a specifically dramaturgical contribution to theatre-making rests in this analysis of the dynamic between performance and spectator'.

In the context of this research, Dramaturgy Sabri Yunus introduce 14 episodes with various themes which covers a wide range of issue related to the community. Among the 14 episodes, the researcher only chose 2 episodes with the same theme. The program selection to be the object for this paper is depending on the consistency of the program shown on the local television channels which are Astro Prima, Astro Warna dan Astro Mustika HD. Furthermore, this selection was also influenced by the professional and local acceptance towards the program.

The episodes selected for this paper research are "Anak Emas" and Batu Belah Batu Tertangkup" episode with the main theme of parental love towards their children. As a Dramaturgy in Comedy, Sabri Yunus has successfully modified the program "karoot komedi" to follow the selected theme.

Two interesting segments in the programme were studied for this paper which was the dikir barat performance and a sketch played by a few professional Comedian, for Anak Emas it was acted by
Jeff and Shuib Sepah Tu, Ebby Yus, Yus Jambu and Nabil while Batu Belah Batu Tertangkup episode was acted by Johan, Jeff \& Shuib Sepah Tu, Ebby Yus and Yus Jambu with special guests, for Anak Emas and Batu Belah Tetangkup episode respectively, were Fauziah Ghouse and Sarah Raisuddin.

Sabri Yunus put the idea into the performance by the application of action, language, logic and also identify which closely portrayed the culture and daily lifestyle of Malays. Thus, these two episodes touch the audience emotions and feelings more than the other 12 episodes. For instances, the Comedian applied the harsh physical humor (slapstick) in the episode "Anak Emas". In this episode, the pregnant wife (acted by Yus Jambu) was pushed harshly off the sofa by her husband (acted by Nabil) just so he could save his mother (acted by Jeff Sepah Tu) who had a hard time breathing.

As a Dramaturgy in Comedy, Sabri Yunus had trained and implemented the Asa Berger Humour Technique in his comedy workpiece by discussing and do various routine practices with the actors and actress on the humor technique until it fits the Asa Berger concept and will be able to make to a realization in Karoot Komedi. As mentioned by Indrayuda (2015, p. 142), the creator of the workpiece is the manager who is able to train and understand the content of his piece which is orientated towards this industry. One of the essential information needed to be known the actors and actress is about the attitude and expression they need to show to the audiences. Both of the information were not far different from the one portrayed by Sabri Yunus in his workpiece "Karoot Komedi". Sabri Yunus able to implement the techniques in his workpiece by emphasizing on the identity played by the actors and actress and logical action which orientated by the Asa Berger humour technique.

\section{Humour and Lelucon}

Humour or lelucon can be inspired by many sources, it can even be inspired from 
unreasonable or strange issues or immoral actions. Those strange issues and immoral acts are able to be acted out with humour with entertainment elements. Humour or lelucon can al.so e the human action or movement that appear as entertaining and makes the audience laugh (Rahmanadji, 2007, pp. 213-215). In this context, Sabri Yunus used this technique and Asa Berger Humour technique in his workpiece Karoot Komedi. In other words, Sabri Yunus tried to apply any humour technique suits for his program which gives an impact to the audience through the identity, language and logical activities portrayed in the performance.

Comedy-dramas or film uses humour techniques as an approach to entertain and garner the audience's interest and also make the audience laugh with the humour reaction portrayed by the actors and actresses. Comedy-dramas and films also hold a happy scene where they intentionally create to entertain the audience, which able to arouse the audience emotion to laugh. That's why the scene will be acted in an exaggerating manner, emphasizing the situation, language used, responses, relationship and also a character (Berger, 2012, p. 2).

In better words, Sabri Yunus has evoked the humour in his workpiece, 'Karoot Komedi' at ASTRO channel. With the application of Asa Berger Humour technique, Sabri Yunus set up a situation, language and action which makes the audience laugh out loud. Sabri Yunus has successfully presented a hilarious situation on the stage with exaggerating the issue, language or even action until it has created a Sabri Yunus's version of interactive communication in the program 'Karoot Komedi'

More so, examples of the application of Asa Berger Humour from the identity aspect, it can be seen that the Dato (acted by Jeff Sepah $\mathrm{Tu}$ ) was flirting with a widow (acted by Ebby Yus) in the Batu Belah Batu Tertangkup episode. This shows how Sabri Yunus creates a character with an unusual behaviour (eccentrivity) as the widow character should be acted out by a woman.

The language used in both episode had also evoked humour in it. For Anak Emas episode, the characters used local dialects such as Perak (spoken by Jeff Sepah Tu) and Negeri Sembilan dialect (spoken by Ebby Yus) which created a conflict as both of the actors tries to understand the meaning and the story of their dialogues. Referring back to the Asa Berger Humour, there were a few elements used in the context such as misinterpreting the situation (misunderstanding), using wordplay (pun), and criticizing someone verbally (ridicule). the next example is through the aspect of logic ABH (Asa Berger Humour) which mentioned the unpredictable situation in a performance (coincidence). This aspect can be seen through Anak Emas episode when the married couple was having a drink and spur the water on each other's body.

From the short segment from the performance idea expressed by Sabri Yunus it is clear that Sabri Yunus has played his roles as a researcher, an Operator, an intermediary and also an initiator in a drama-comedy performance.

Humour techniques have made comedy-drama and films more lively and attract audience attention and also makes them laugh. Humour technique itself is a message conveyed in the film or drama with humour, and also functions as a stress reliever, making bonds between humans, evoke happy emotion and also avoid any stress emotion to evoke from the human (Sugiarto, 2016, p. 4).

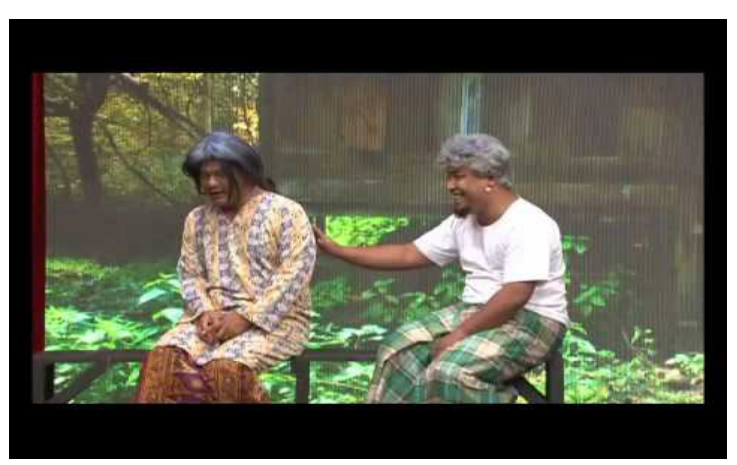

Figure 1. Batu Belah Batu Bertangkup Episode 


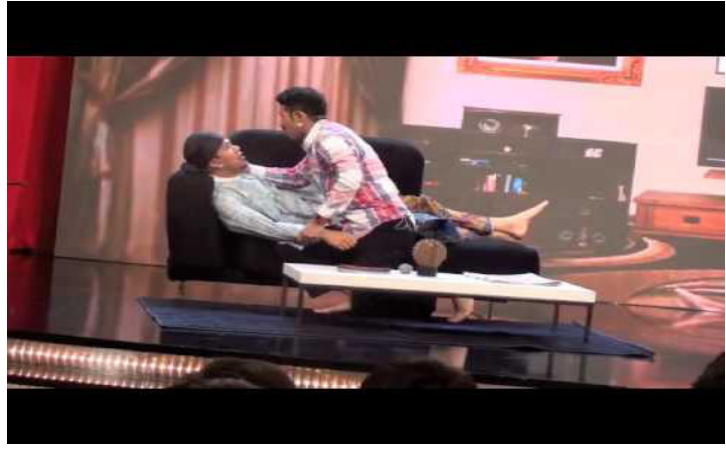

Figure 2. Anak Emas Episode

According to a communication research, a humour would be a success the moment (the person who receive the humour) understands the meaning behind it from the humour stimulation conveyed by the comedian (communicator/humour actor) Humour stimulus refers to the hilarious actions that evoke a smile or laughter caused by accepting the humour (Rahmanadji, 2007). Based on Rahmanadji's research, Sabri Yunus along with the Asa Berger Humour concept has successfully create a humour performance where the language, logic, identity and action portrayed were able to touch the audience's heart with the humour action acted by the comedian in the 'Karoot Komedi' performance on Malaysia Television cable, ASTRO. This was done by Sabri Yunus as a dramaturgy who is able to analyze the local people situation until his workpiece contents with humour that is easy to understand by the audience.

Romanska stated that a dramaturgy needs to analyze, have communication skills and also a basic understanding of aspects of theater which will help them in connecting the text with the performance. For quality and high-class dramaturgy performance, producers should not fear constructive criticism (break down the walls) from the academic professors and art performance artists.

Even if an art or art piece continues to exist in the community for its values, it needs to go through various alteration and most of the alteration is due to make the performance more creative. As a consequence, there will be an issue on the original and new version of the performance due to the new technique used (Saerani, $2015,78)$. This can be seen in the program 'Karoot Komedi' produced by Sabri Yunus, where the humour techniques can be seen in the comedy piece until the restricted limitation as in the Java dance art technique can occur in a drama piece orientated on the Asa Berger humour technique. Compromising will still happen in the construction as it is viewed as a creative work piece for the Karoot Komedi by Sabri Yunus even with the limitation set.

According to Hadaway (2015:9) it is important for a dramaturgy to 'Analyze the text, do the Research needed and Apply that wisdom to your artistry, for your audience'. in Hadaway's research, there are 3 aspects needs to be considered by the dramaturgy while editing a workpiece. These 3 aspects will able to help in upgrading the level of the dramaturgy thinking. A dramaturgy needs to be more creative and critical toward theater workers. Therefore, a dramaturgy needs to (a) analyze a literature piece aesthetics with the dramatic elements in it; (b) when reviewing the drama texts, Hadaway advises to make sure the performance to be set as similar as a daily life routine of the community; ( c) a dramaturgy also needs to be smart to arouse the audience's emotion to enable the audience to feel and appreciate the emotion play in the performance.

In order to give a positive impact in performance it needs to involve a dramaturgy perpetrator in origination or in production. The implementation of the ideas from dramaturgy perpetrator will able to help the development of the whole origination or production. Furthermore, the issues and solution presented will be more effective for the audience to overcome their problem. Inserting dramaturgy in origination or a production able to create a more creative environment in the scenes in a performance. The effective dramaturgy involvement is focused on 3 phases; before, during and after the performance.

The text for a film or a drama piece uses the Asa Berger concept in relating to the socio-cultural contexts where it will de- 
velop accordingly to the situation and condition of the text through the use of language. In other words, language is a medium to a communication media. In this context, the text mentioned is a text or a language used in humorous a film or drama such as Warkop DKI (Hartono, 2015, p. 8). Referring to the matter, Sabri Yunus is brilliant in choosing the words or language that will make an audience of Karoot Komedi laughing, of which talks about the collective socio-culture value in a community. This is the socio-culture value portrayed in a humorous drama comedy, Karoot Komedy which airs on the television channel ASTRO. This shows the use of humour technique, language, using specifically in the Asa Berger humour technique context. In the application of Asa Berger humour concept and the dramaturgy perspective in Karoot Komedi, Sabru Yunus plays a role of a researcher, as Sabri Yunus did an observation towards the character and behaviour of Malaysia's society along with the character as a humour identity in the program, before the idea could put into realization.

Sabri Yunus held a firm belief on the humour concept application from his approach towards the local culture until the cultural aspect becomes an idea to be produced in Karoot Komedi. With all the dramaturgy values Sabri Yunus owns, he pours it all by applying the Asa Berger concept in his workpiece, Karoot Komedi. Sabri Yunus's effectiveness in planning, managing, and applying the humour concept in his comedy piece, Karoot Komedi was created through a dramaturgy perspective. According to the dramaturgy aspects that Sabri Yunus practice, it will enable him to realize all his idea will only the application of Asa Berger Humour technique.

\section{CONCLUSION}

Dramaturgy perpetrator function as a researcher is to obtain data of an idea in a performance by conducting research. Conducting further research on the idea on the history and how the people during the time dresses, a drama piece such a folks legend drama can be set accordingly to make the audience feel they are part of the play. A dramaturgy perpetrator also does research on the politic or mythology perspective that could influence performance.

A dramaturgy perpetrator is also a collector who will collect suitable material to be used in a performance. Therefore, in Karoot Komedi, aired in Astro television channel, Sabri Yunus has collected all the materials needs for the set in order for the actors do their part in the performance successfully. The materials are not only be used during a performance but also in rehearsals.

A dramaturgy perpetrator has the privilege to choose the script of a performance before the producer decided on the concept or form of the performance. The dramaturgy perpetrator may need to consider how the concepts they want can suit the producer's needs.

Asa Berger humour technique is a technique widely used by dramaturgy perpetrators. The most prominent technique used is on how the used of simple and friendly language can turn the performance into a communicative program where all the messages conveyed by the actors will able to make the audience laugh. Moreover, language plays a role in the issues covered in the performance to be realistic and logical until it was able to make the audience immerse into the performance. A comedy piece can be successful for the communication between the audiences and the issue presented to them. This also includes the humour perpetrator action who able to express the context of the story by interacting with audiences.

Sabri Yunus is a dramaturgy figure with his drama humour piece with the use of Asa Berger humour concept. The Asa Berger humour concept such as the use of a friendly language with the audience, logical story settings and simple performance that could be understood by the audience in the cultural aspect, and drama actors' alluring gestures on stage.all of the four aspects was practiced by Sabri Yunus com- 
municative manner. Sabri Yunus has successfully applied the Asa Berger Humour technique from the dramaturgy's perspective. The humour technique done with the dramaturgy perspective considers various aspects such as the stage, acting, setting, dialogue and communicative interaction, work for the Karoot Komedi piece to be accepted and enjoyed by Astro subscribers with positive feedback.

The implementation of the ideas through dramaturgy enables to develops throughout the whole Karoot Komedi production until the Asa Berger humour technique was able to be applied successfully. The drama production was able to create a more creative local atmosphere with the involvement of dramaturgy in an organization or a drama production. The involvement of dramaturgy before, during and after the drama is aired is a wise procedure to implement in a performance's process.

\section{ACKNOWLEDGEMENT}

I want to take this moment to express my gratitude to my co-writer, Mohd Effindi Bin Shamsuddin Universiti Malaya, Malaysia and also Indrayuda Universitas $\mathrm{Ne}-$ geri Padang, Indonesia for always keeping me motivated to complete this research. Not to forget to show my appreciation to The Ministry of Education for sponsoring my $\mathrm{Ph}$. D research for these past 3 years. Last but not least, a very special thanks to Sabri Yunus and his co-workers who were willing to give their time and cooperation for this research. (Hadaway, 2015)

\section{REFERENCES}

Azizah, N. (2012). Presentasi Diri Anggota Komunitas Hijabers : Studi Dramaturgi Tentang Presentasi Diri Anggota Komunitas Hijabers di Kota Bandung. Thesis of under graduate. Bandung: UNIKOM.

Mohd Al Qayum Azizi. (2014). Istana Budaya Minta Pelawak Tidak Sentuh Isu Agama Dalam Persemba- han - Hiburan | mStar. Retrieved December 24, 2018, from https:// www.mstar.com.my/spotlight/hiburan/2014/05/13/istana-budaya

Barba, E. (2010). On Directing and Dramaturgy: Burning The House. New York: Routledge Publications

Behrndt, S. K. (2015). Dramaturgy in the making: a user's guide for theatre practitioners. Journal Studies in Theatre and Performance, 35(3), 253 254.

Berger, A. A. (2012). An Anatomy of Humor. United States of America: Transaction Publishers.

Charlene, R. (2016). Symposium Asian Dramaturgy Network. Singapore.

Hadaway, R. (2015). Dramaturgy: Kurt Well's Street Scene': An American Opera and the American Immigrant's Experience. Kennesaw State University. Retrieved from https://digitalcommons.kennesaw.edu/etd/677/

Hartono, L. (2015). Teknik Humor dalam Film Warkop DKI. Komunikasi, 3(1).

Harymawan. (1988). Dramaturgii. Bandung: CV Rosda.

Hussain, Safian (1981). Sejarah Kesusasteraan Melayu. Kuala Lumpur:Dewan Bahasa dan Pustaka

Indrayuda, I. (2015). Continuity of Tradition Dance: Academicians' Intervention on Artists and Performing Arts Groups. Harmonia: Journal of Arts Research and Education, 15(2).

Ismail, A. (2007). Utusan Malaysia Online. Diterbitkan: Isnin, 30 Julai 2007

Lessing, G.E. (1962). Hamburg Dramaturgi. US: Dover Publications

Marianne Van Kerkhoven. (1988.) Short comments on the notion of European Dramaturgy

Marianne Van Kerkhoven (2009). A constant movement. Journal of the Performing Arts, 14(3), 7-11

Raliby, Osman (1956). Kamus internasional. Bulan Bintang:Djakarta

Rahmanadji, D. (2007). Sejarah, Teori, Jenis, dan Fungsi Humor. Jurnal Bahasa dan Seni, 35(2), 213- 215

Romanska, M (2016). The Routledge Com- 
panion to Dramaturgy. New York: dan kritikan sastera. Kuala Lumpur:

Routledge Publications

Dewan Bahasa dan Pustaka

Saearani, M. F. T. B. (2015). The Roles of

The Dance Education Institute and

The Ngayogyakarta Hadiningrat

Palace in The Inheritance Process of

Yogyakarta Classical Dance Style.

Harmonia: Journal of Arts Research and Education, 15(1), 77-87.

Sikana, M. (2013). Dari barat ke timur: teori

Sugiarto, V. D. (2016). Teknik Humor dalam Film Komedi yang Dibintangi oleh Stand Up Comedian. Komunikasi, 4(2), 4

Trencsenyi, Katalin. (2015). Dramaturgy in the Making: A User's Guide for Theatre Practitioners. London: Bloomsbury Publishing 